\title{
Penerapan Senam Kaki Diabetik Untuk Peningkatan Sensitivitas Kaki Pada Pasien Diabetes Mellitus Tipe 2
}

\author{
Ismiyati $^{1 *}$, Herni Rejeki ${ }^{2}$ \\ 1,2 Program Studi Diploma Tiga Keperawatan, Universitas Muhammadiyah Pekajangan Pekalongan, \\ Indonesia \\ *email: ismy2303@gmail.com
}

\begin{abstract}
Diabetes mellitus is a disorder characterized by elevated blood sugar levels, due to abnormalities in insulin secretion. This results in nerve cells edema and triggers the stimulation of various enzymes that can damage nerve cell through both metabolic and neurovascular factors. This condition will interfere with the supply of blood and oxsygen to the nerve cells, especially in the peripheral areas of the feet and hands. To prevent this, it is neccesary to do diabetic foot exsercises in people with diabetes mellitus. This scientific paper focused on two famillies with diabetes mellitus. the result stated applying diabetic food exercises for the patient is the efective and it could be done once a day. Furthermore, it also can help improve blood circulation in the legs. Through movements in diabetic food exercises, the muscles will contract so that it will increase the sensitivity of the feet in poeple with diabetes mellitus. Even if it is done routinely, it can prevent the occurrence of non-ulcer wounds or ulcers. Therefore, it is expected for the familly to support the patient in applying the exercises.
\end{abstract}

Keywords: Diabetic Foot Exercises, Foot Sensitivity

\begin{abstract}
Abstrak
kadar gula dalam darah yang diakibatkan karena kelainan sekresi insulin akibatnya edema sel saraf serta memicu stimulasi berbagai enzim yang dapat merusak sel saraf baik melalui faktor metabolik maupun faktor neurovaskular, hal terdebut akan mengganggu suplai darah dan oksigen menuju sel saraf terutama di daerah perifer kaki dan tangan. Untuk mencegah akibat tersebut dilakukan senam kaki diabetik pada penderita Diabetes Mellitus. Fokus karya tulis ilmiah adalah 2 keluarga dengan Diabetes Mellitus Hasil penerapan senam kaki diabetik yang di lakukan untuk meningkatkan sensitivitas kaki pada penderita Diabetes Mellitus efektif untuk di terapkan pada penderita Diabetes Melitus bila dilakukan secara rutin satu kali sehari, senam kaki diabetik dapat membantu melancarkan sirkulasi darah pada kaki, melalui gerakan pada senam kaki diabetik otot-otot akan berkontraksi sehingga akan meningkatkan sensitivitas kaki pada penderita Diabetes Mellitus. Bahkan jika dilaukan secara rutin dapat mencegah terjadinya luka non ulkus ataupun luka ulkus. Di harapkan keluarga memberikan dukungan pada keluarga yang sakit dengan mendampingi saat melakukan latihan senam kaki diabetik.
\end{abstract}

Kata kunci: Senam Kaki, Sensitivitas Kaki

\section{Pendahuluan}

Diabetes mellitus merupakan suatu kelompok kelainan yang ditandai dengan naiknya kadar gula dalam darah yang diakibatatkan karena kelainan sekresi insulin (Sanjaya Putu Budhi, et al. 2019) Diabates mellitus merupakan penyakit yang membutuhkan pengobatan seumur hidup dalam mengontrol kadar gula darah, agar dapat meningkatkan kualitas hidup penderita, seseorang dikatakan hiperglikemia 


\section{Prosiding Seminar Kesehatan Nasional Lembaga Penelitian dan Pengabdian Masyarakat Universitas Muhammadiyah Pekajangan Pekalongan}

ketika tekanan gula dalam darah lebih dari $130 \mathrm{md} / \mathrm{dL}$ (Sulistyowati \& Asnindari, 2017 dalam Khaerunnisa Nur \& rahmawati. 2019 ). Penimbunan fruktosa di dalam sel saraf menyebabkan edema sel saraf serta memicu stimulasi berbagai enzim yang dapat merusak sel saraf baik melalui faktor metabolik maupun faktor neurovaskular, hal terdebut akan mengganggu suplai darah dan oksigen menuju sel saraf terutama di daerah perifer kaki dan tangan (Subekti, 2009 dalam Sanjaya Putu Budhi, et al. 2019).

Menurut World Healt Organization (WHO,2017) jumlah orang dengan kasus diabetes mellitus meningkat dari 108 juta jiwa pada tahun 1980 menjadi 422 juta pada tahun 2014. Menurut International Of Diabetic Ferderation (IDF, 2015) prevalensi diabetes mellitus secara global pada tahun 2014 sebesar 8,3\% dari keseluruhan penduduk di dunia dan mengalami peningkatan pada tahun 2014 menjadi 387 juta kasus. Indonesia merupakan negara menempati urutan ketujuh dengan penderita DM sejumlah 8,5 juta penderita setelah Cina, India dan Amerika Serikat, Brazil, Rusia, Mexiko. Angka kejadian DM menurut data Riskesdas (2019) terjadi peningkatan 1,1\% di tahun 2007 meningkat menjadi 2,1\% di tahun 2013 dari keseluruhan penduduk sebanyak 250 juta jiwa. Provinsi Jawa Tengah memiliki angka prevalensi 83,1\%. Presentasi Diabetes Melitus tertinggi dikota atau kabupaten daerah jawa tengah adalah kabupaten Purbalingga yaitu $134.5 \%$ dan yang terendah adalah kabupaten Pemalang yaitu 26.3\%. sedangkan untuk angka prevalensi Brebes adalah 90.0\% (Dinkes Provinsi Jawa Tengah, 2018).

Studi kasus ini dilakukan di Kelurahan Pengabean, Kecamatan Losari Kabupaten Brebes. Penderita Diabetes Mellitus yang ditemukan pada wilayah tersebut yaitu sebanyak 8 orang, dan belum pernah dilakukan terapi non farmakologi seperti senam kaki diabteik. Terdapat metode non farmakologi yang dapat dilakukan pada penderita Diabetes Mellitus seperti senam kaki diabetik.

Salah satu upaya untuk meningkatkan sensitivitas kaki dengan melakukan perawatan kaki secara teratur dapat mengurngi penyakit diabetik seebesar $50-60 \%$. Untuk meningkatkan vaskularisasi perawatan kaki dapat juga dilakuan dengan gerakan-gerakan kaki yang dikenal sebagai senam kaki diabetic (Black \& Hawks, 2009; Smeltzr et al.,2010; Lewis et al., 2011).

Senam kaki diabetik merupakan salah satu tindakan nonfarmakologi yang dapat dilakukan pada penderita Diabetes Mellitus yang dapat meningkatkan sensitivitas. Latihan senam kaki diabetik menyebabkan terjadinya peningkatan aliran darah, hal ini menyebabkan lebih banyak tersedia reseptor insulin dan reseptor menjadi aktif yang akan berpengaruh terhadap penurunan glukosa darah pada pasien diabetes mellitus (Sulistyowati \& Asnindari, 2017). Penerapan senam kaki diabetik ini sudah dibuktikan oleh peneliti Sanjaya putu budhi (2019) menyatakan bahwa terdapat pengaruh yang signifikan senam kaki diabetik terhadap sensitivitas kaki pada pasien Diabetes Mellitus tipe 2.

\section{Metode}

Rancangan Karya tulis ilmiah ini dibuat dengan rancangan studi kasus. Rancangan studi kasus adalah metode deskriptif metode yang menggambarkan situasi yang ada saat ini berdasarkan masalah yang ada sehingga menghasilkan data dengan baik dan 


\section{Prosiding Seminar Kesehatan Nasional 2021 Lembaga Penelitian dan Pengabdian Masyarakat Universitas Muhammadiyah Pekajangan Pekalongan}

lengkap dengan kriteria yang diambil ialah penurunan sensasi protektif kaki pada pasien Diabetes Mellitus.

Studi kasus ini akan dilaksanakan di Kelurahan Pengabean, Kecamatan Losari, Kabupaten Brebes, dimulai dari bulan November 2020 sampai bulan Mei 2021. Subjek studi kasus dalam karya tulis ilmiah ini menggunakan 2 keluarga dengan keluarga yang mengalami penurunan sensasi protektif kaki pada pasien Diabetes Mellitus.

\section{Hasil dan Pembahasan}

\section{Hasil}

Asuhan keperawatan yang telah dilakukan terhadap 2 keluarga yaitu keluarga Ny.S dan Ny.S terkait dengan masalah penurunan sensitifitas kaki pada pasien Diabetes Mellitus di Desa Pengabean Kecamatan Losari Kabupaten Brebes. Asuhan keperawatan meliputi pengkajian, diagnosa keperawatan, intervensi keperawatan, implementasi keperawatan, dan evaluasi keperawatan. Implementasi difokuskan pada penerapan senam kaki diabetik untuk meningkatkan sensitivitas kaki pada pasien Diabetes Mellitus.

Hasil pengkajian yang sudah dilakukan pada klien I dan II penulis mrumuskan diagnosa yaitu: Ketidakefektifan perfusi jaringan perifer, Ketidakstabilan kadar glukosa darah. Intervensi yang akan diberikan pada klien I dan II adalah 1) Kaji kemampuan keluarga dalam mengenal senam kaki diabetik, 2) Monitor TTV dan cek sensitivitas kaki sebelum dan sesudah dilakukan senam kaki diabetik, 3) Berikan pendidikan kesehatan tentang diet makanan Diabetes Mellitus, 4) Berikan penyuluhan tentang pentingnya melakukan pemeriksaan kesehatan, 5) Kolaborasi dengan keluarga untuk memantau latihan senam kaki diabetik.

\begin{tabular}{|c|c|c|c|}
\hline $\begin{array}{c}\text { Pertemuan/Ta } \\
\text { nggal }\end{array}$ & Intervensi & Klien I & Klien II \\
\hline $\begin{array}{c}1 \\
22 \text { maret } \\
20211\end{array}$ & Sesudah & $\begin{array}{l}\text {-Kedua kaki merasakan } \\
\text { Kesemutan dan kebas } \\
\text {-Kaki masih merasakan } \\
\text { kesemutandan kebas }\end{array}$ & $\begin{array}{l}\text {-Kedua kaki merasakan Kesemutan dan } \\
\text { kebas } \\
\text {-Kaki masih merasakan Kesemutan dan } \\
\text { kebas }\end{array}$ \\
\hline $\begin{array}{c}2 \\
23 \text { maret } 2021\end{array}$ & $\begin{array}{l}\text { Sebelum } \\
\text { Sesudah }\end{array}$ & $\begin{array}{l}\text {-Kedua kaki merasakan } \\
\text { Kesemutan dan kebas } \\
\text {-Kaki masih merasakan } \\
\text { Kesemutan dan kebas }\end{array}$ & $\begin{array}{l}\text {-Kedua kaki merasakan Kesemutan dan } \\
\text { kebas } \\
\text {-Kaki masih merasakan Kesemutan dan } \\
\text { kebas }\end{array}$ \\
\hline $\begin{array}{c}3 \\
24 \text { maret } 2021\end{array}$ & $\begin{array}{l}\text { Sebelum } \\
\text { Sesudah }\end{array}$ & $\begin{array}{l}\text {-Kedua kaki merasakan } \\
\text { Kesemutan dan kebas } \\
\text {-Kaki masih merasakan } \\
\text { Kesemutan dan kebas }\end{array}$ & $\begin{array}{l}\text {-Kedua kaki merasakan Kesemutan dan } \\
\text { kebas } \\
\text {-Kaki masih merasakan Kesemutan dan } \\
\text { kebas }\end{array}$ \\
\hline $\begin{array}{c}4 \\
25 \text { maret } 2021\end{array}$ & $\begin{array}{l}\text { Sebelum } \\
\text { Sesudah }\end{array}$ & $\begin{array}{l}\text {-Kedua kaki merasakan } \\
\text { Kesemutan dan kebas } \\
\text {-Kaki masih merasakan } \\
\text { Kesemutan dan kebas }\end{array}$ & $\begin{array}{l}\text {-Kedua kaki merasakan Kesemutan dan } \\
\text { kebas } \\
\text {-Kaki masih merasakan Kesemutan dan } \\
\text { kebas }\end{array}$ \\
\hline $\begin{array}{c}5 \\
26 \text { maret } 2021\end{array}$ & $\begin{array}{l}\text { Sebelum } \\
\text { Sesudah }\end{array}$ & $\begin{array}{l}\text {-Kedua kaki merasakan } \\
\text { Kesemutan sudah tidak } \\
\text { kebas kebas } \\
\text {-Kaki masih merasakan } \\
\text { kesemutansudah tidak kebas } \\
\text { kebas }\end{array}$ & $\begin{array}{l}\text {-Kedua kaki merasakan kesemutan. } \\
\text { sudah tidak kebas kebas } \\
\text {-Kaki masih merasakan Kesemutan } \\
\text { sudah tidak kebas kebas }\end{array}$ \\
\hline
\end{tabular}




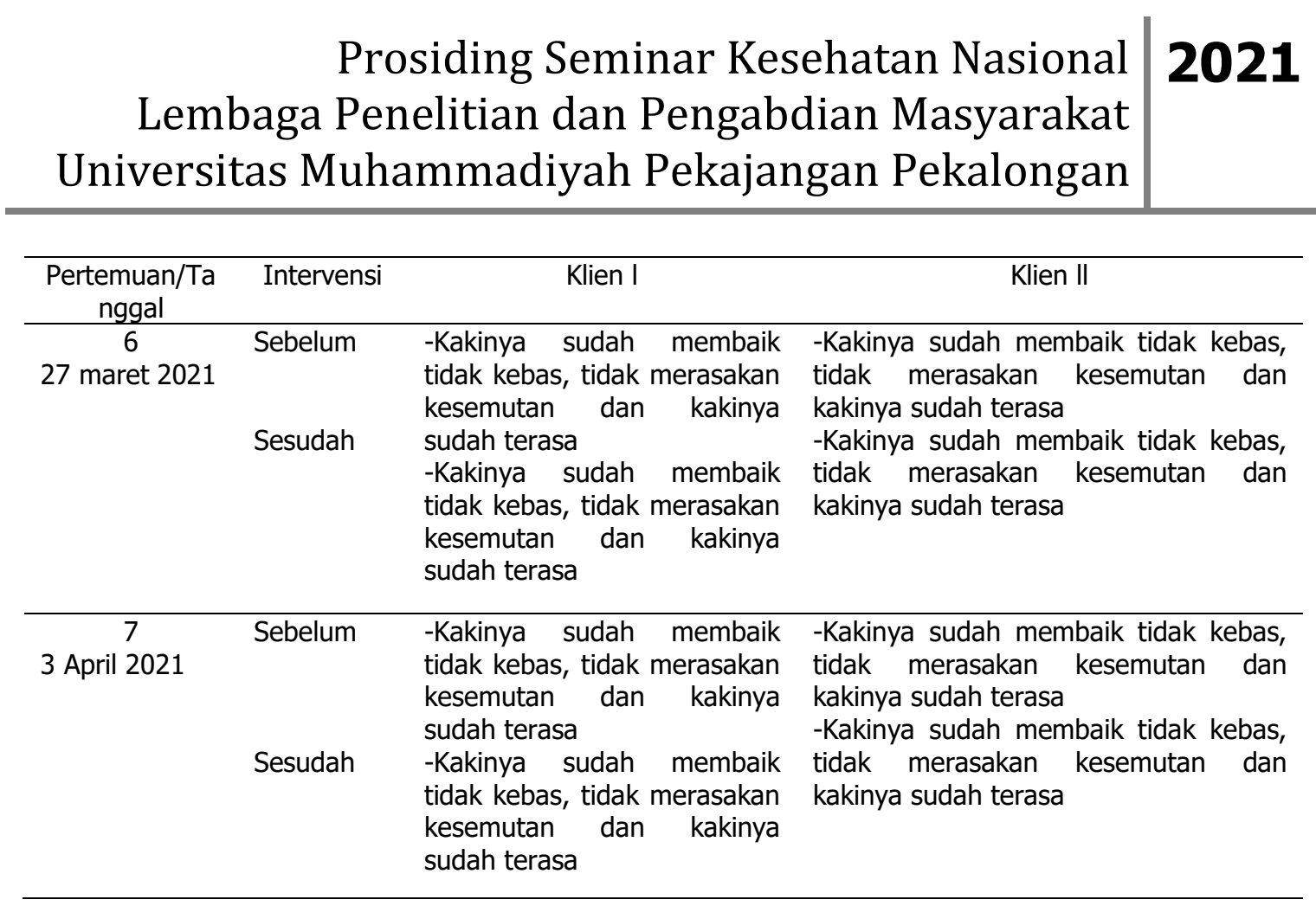

\section{Pembahasan}

Latiahan senam kaki diabetik yang telah dilakukan terhadap 2 keluarga selama 14 hari penulis melakukan evaluasi bahwa pada kedua pasien mengalami peningkatan sensitivitas kaki hal ini karena ke 2 pasien melakukan latihan senam kaki diabetik secara rutin. Hal ini sesuai dengan teori Purwanto (2013) akan bermanfaat untuk meningkatkan sensitivitas kaki karrena dapat melancarkan sirkullasi darah pada kaki.

$\mathrm{Hal}$ ini sesuai dengan teori yang menyatakan bahwa senam kaki diabetik dapat membantu melancarkan sirkulasi darah pada kaki, melalui gerakan pada senam kaki diabetik otot-otot akan berkontraksi sehingga akan meningkatkan sensitivitas kaki Smeltzer Bare, (2002) dalam jurnal Sanjaya Putu Budhi, et al. (2019).

\section{Kesimpulan}

Berdasarkan hasil penerapan senam kaki diabetik yang di lakukan untuk meningkatkan sensitivitas kaki pada penderita Diabetes Mellitus efektif untuk di terapkan pada penderita Diabetes Melitus bil dilakukan secara rutin satu kali sehari senam kaki diabteik dapat membantu melncarkan sirkulasi darah pada kaki, melalui gerakan pada senam kaki diabetik otot-otot akan berkontraksi sehingga akan meningkatkan sensitivitas kaki pada penderita Diabetes Mellitus. Bahkan jika dilaukan secra rutin dapat mencegah terjadinya luka non ulkus ataupun luka ulkus.

\section{Ucapan Terima Kasih}

Penulis mengucapkan terimaksi kepada semua pihak yang telah membantu dalam pembuatan karya tulis ilmiah ini. Terkhusus untuk dosen pembimbing yang syudah sabar dalam membimbing dan mendampingi penulis selama proses pembuatan karyatulis ilmiah.

\section{Referensi}

[1] Bakri, M.H. (2018). Asuhan Keperawatan Keluarga. Yogyakarta: Pustaka Mahardika 


\section{Prosiding Seminar Kesehatan Nasional 2021 Lembaga Penelitian dan Pengabdian Masyarakat Universitas Muhammadiyah Pekajangan Pekalongan}

[2] Dinas Kesehatan Provinsi Jawa Tengah (2019). Profil Kesehatan provinsi Jawa Tengah Tahun 2019. Dinkes Jawa Tengah 2017. http://dinkesjatengprov.go.id/v2018/dokumen/profil2019/mobile/index.html\#p= $\underline{122}$

[3] Latifah, S., Fahdi, F. K., \& Hafidzah, R. Pengaruh Senam Kaki Diabetes Terhadap Sensitivitas Kaki Pada Pasien DIABETES Melitus Tipe 2 Di UPTD RSUD Sultan Syarif Mohamad Alkadrie Kota Pontianak. Jurnal ProNers, 3(1).

[4] Manurung, Nixson. 2018. Keperawatan Medikal Bedah Konsep,Mind Mapping, dan Nanda NIC NOC Solusi Cerdas Lulus UKOM Bidang Keperawatan Jilid 1. Jakarta: CV. Trans Info Media

[5] Nurarif, Amin Huda \& Kusuma Hardhi. (2016). Asuhan Keperawatan Praktis Berdasarkan Penerapan Diagnosa Nanda, Nic, Noc dalam Berbagai Kasus. Yogyakata: MedIaction Publishing

[6] Padila. (2019). Buku Ajar : Keperawatan Medikal Bedah. Yogyakarta: Nuha Medika

[7] Riasmini, Made, N. Dkk. (2017). Panduan Asuhan Keperawatan : Individu Keluarga, Kelompok Dan Komunitas Dengan Modifikasi Nanda, INCP, Noc Dan Nic Di Puskesmas dan Masyarakat. Jakarta. Penerbit Univertas Indonesia (UI Press).

[8] Ruben, G., Rottie, J., \& Karundeng, M. (2016). Pengaruh Senam Kaki Diabetes Terhadap Perubahan Kadar Gula Darah Pada Pasien Diabetes Melitus Tipe 2 Di Wilayah Kerja Puskesmas Enemawira. Jurnal Keperawatan, 4(1).

[9] Said, R. (2018). Penerapan Senam Kaki pada Pasien Diabetes Mellitus Tipe 2 dalam Pemenuhan Kebutuhan Keamanan dan Proteksi (Integritas Kulit/jaringan) di Wilayah Kerja Puskesmas Mamajang. Media Keperawatan: Politeknik Kesehatan Makassar, 9(2), 160-166.

[10] Sanjaya, P. B., Yanti, N. L. P. E., \& Puspita, L. M. (2019). Pengaruh Senam Kaki Diabetik Terhadap Sensitivitas Kaki Pada Pasien Dm Tipe 2. Coping: Community of Publishing in Nursing, 7(2), 97-102. 